\title{
Chapter 18 \\ Implementing Nature-Based Solutions \\ in Urban Areas: Financing and Governance Aspects
}

\author{
Nils Droste, Christoph Schröter-Schlaack, Bernd Hansjürgens, \\ and Horst Zimmermann
}

\begin{abstract}
Fostering nature-based solutions in urban areas is an issue that receives increasing attention on the political agenda. But in many cases, only insufficient financial resources are available for the implementation of such solutions. A central issue in this context is the structure of municipal revenues, which stem from either municipal tax revenue, fees for municipal services, or fiscal transfers from other governmental levels. Many of these revenues are however absorbed by specific tasks, especially social expenditure; thus there is little room left for autonomous investments, e.g. into nature-based solutions and green infrastructure. In this chapter we elaborate on the structure of the problem such as the corresponding fiscal and constitutional restrictions and analyse which solutions are possible to allow for greater investments into multifunctional urban nature-based solutions.
\end{abstract}

Keywords Nature-based solutions - Public finance - Municipal revenues • Municipal expenditures $\bullet$ Urban governance

\subsection{Introduction: The Nature of Nature-Based Solutions}

Nature-based solutions (NBS) in urban areas are receiving increasing attention not only in research but especially on the political agenda. While environmental friendly and ecologically sound practices of agriculture, infrastructure development and human settlements have at least been promoted politically since the Earth Summit

\footnotetext{
N. Droste $\bullet$ C. Schröter-Schlaack $\bullet$ B. Hansjürgens $(\bowtie)$

UFZ - Helmholtz Centre for Environmental Research,

Permoserstraße 15, 04318 Leipzig, Germany

e-mail: nils.droste@ufz.de; christoph.schroeter-schlaack@ufz.de;

bernd.hansjuergens@ufz.de
}

H. Zimmermann

Philipps University of Marburg, Marburg, Germany

e-mail: horstzimmermann1@ freenet.de 
in Rio 1992, the idea of employing natural elements to substitute and complement man-made infrastructure and production systems is a rather recent development. During the last decades, there has been more and more research focusing on NBS (see as a general introduction ten Brink et al. 2012). At the same time there is an increasing interest on the political level (a prominent example provides the latest EU research strategy; see EC 2015).

Nature-based solutions are multifunctional, i.e. they deliver manifold services at the same time. For example, an urban park is not only a place of recreation for people (and sometimes a touristic factor) but also a corner-stone for (urban) biodiversity. The park is providing cooling effects important for reducing heat stress induced by climate change, relieving public sewerage infrastructures in case of heavy rainfall by providing natural seepage, filtering particular matters and dust and reducing noise of, e.g. traffic, and is contributing to climate change mitigation via carbon sequestration of its vegetation. While on the one hand, the multifunctionality of NBS promises high social return on investments, since they simultaneously address several societal goals, it is on the other hand hard to develop financial arrangements for their realization, since their superiority only becomes visible if all services are considered. Sectorial returns, e.g. in terms of noise reduction, are often falling short of benefits provided by technical and grey infrastructure solutions such as noise-insulating walls.

While there is yet lacking a clear definition (Potschin et al. 2015), the idea of employing nature to satisfy human needs has attracted both conservation experts such as the International Union for Conservation of Nature (IUCN 2016) and major infrastructure investors such as the World Bank (2008). The expert group of the "Nature-Based Solutions and Re-naturing Cities" of the European research programme Horizon 2020 defined NBS as actions inspired by, supported by or copied from nature; [...] [that] use the features and complex system processes of nature, such as its ability to store carbon and regulate water flows, in order to achieve desired outcomes, such as reduced disaster risk and an environment that improves human well-being and socially inclusive green growth (EC 2015, p. 24). The concept therefore aims at satisfying human needs by utilizing (cultivated and humanly formed) natural systems. Regarding the urban environment, the idea is to foster multifunctional green spaces, green roofs, roadside greeneries, etc. to improve human health and human well-being.

There are potential similarities and overlaps to concepts such as the "ecosystem approach, ecosystem services, ecosystem-based adaptation/mitigation and green and blue infrastructure" (EC 2015, p. 24). Thus, many different aspects have been addressed from various perspectives; at the same time, however, many details have not been clarified yet.

For an actual implementation, financing aspects are certainly among the issues which are of utmost importance. While we assume that there is no easy blueprint, one-size-fits-all solution, we aim at elaborating on the issue from a perspective of public finance and public choice. Hence, our basic premise is that, in urban areas, public bodies are central actors that provide the required investments for the implementation of NBS. The goal of this chapter is therefore to clarify how cities and municipalities may leverage required investment volumes for NBS. Focussing on municipal actors, the chapter serves three purposes: 
1. We provide an overview about potential instruments for implementing NBS and their adoptions at the local and/or regional level (Sect. 18.2).

2. We highlight obstacles for financing NBS regarding the structure and purposes of municipal budgets (Sect. 18.3), for which we will discuss examples from the German institutional setting.

3. We elaborate on selected proposals on how to overcome these barriers and leverage greater investments into urban NBS (Sect. 18.4).

\subsection{Policy Instruments for Nature-Based Solutions}

Policy instruments for implementing NBS in urban environments are manifold and touch upon almost every single policy area in the urban context. Generally, policy instruments cover a range from rather weak but basic tools such as informational systems like monitoring and accounting, over command-and-control instruments such as municipal green planning, to economic instruments that set incentives via prices or quantity mechanisms. This classification can be extended into the direction of instruments that foster cooperation, since NBS often require interdepartmental teamwork or the support of other governments at the same level (horizontal cooperation) or at upper levels (vertical cooperation) through corresponding programmes.

Figure 18.1 provides an overview of potential instruments, which we briefly introduce. For the practical examples, we refer to the work on incorporating ecosystem

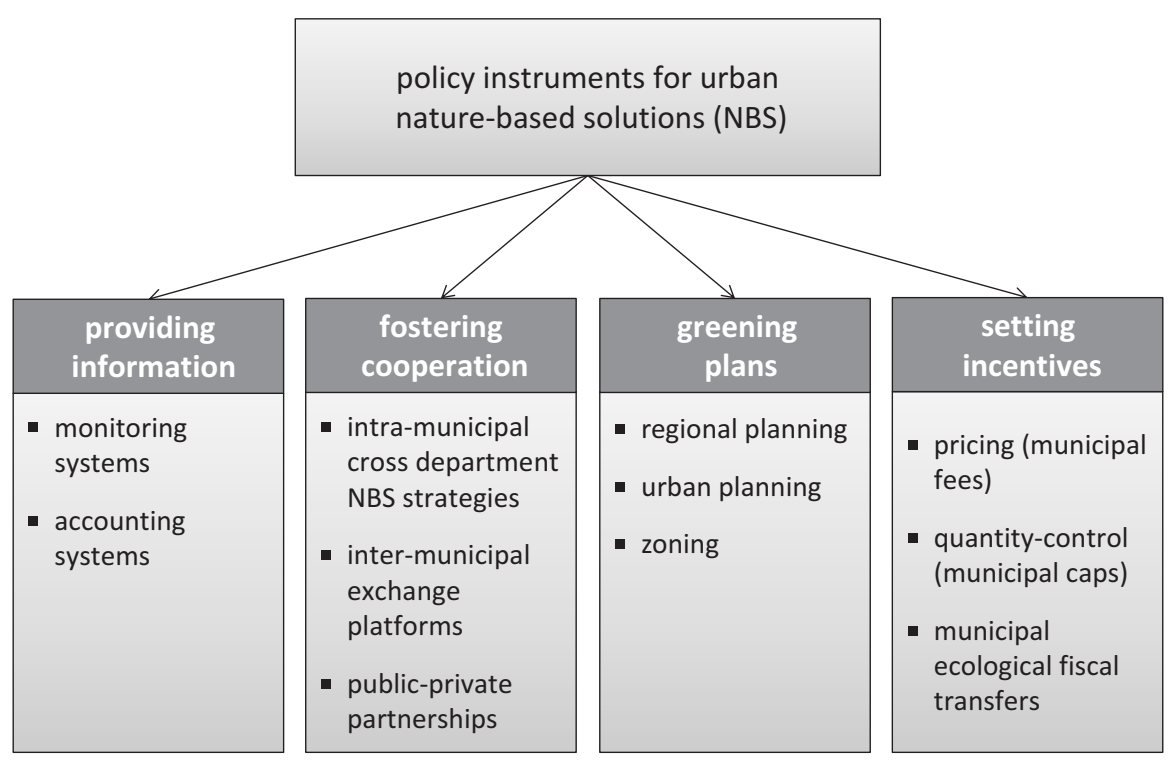

Fig. 18.1 Instruments for implementing nature-based solutions (Source: Adapted from Naturkapital Deutschland - TEEB DE 2016) 
services into urban policy-making by the German Natural Capital Project (Naturkapital Deutschland - TEEB DE 2016) which is based on the international TEEB study "The Economics of Ecosystems and Biodiversity" (TEEB 2012).

\subsubsection{Informational Tools}

At the most basic and fundamental level, green infrastructure planning that implements NBS requires information, for example, about benefits and costs of particular projects or project alternatives. Therefore, the ecosystem services provided by NBS and the natural capital that is accumulated by investing in green infrastructure have to be monitored and translated into accounting systems.

While there are exceptional NBS showcases that are well analysed and researched (see TEEB 2012; Naturkapital Deutschland - TEEB DE 2016), there is no coherent and comprehensive assessment of the natural capital stocks and ecosystem service flows in urban areas. Cooling effects of urban green spaces that increase climate change resilience can contribute to reducing stress factors that stem from overheating and that lead to serious health-related impairments and result in increased morbidity and mortality rates (Gabriel and Endlicher 2011; Heudorf and Meyer 2005; Hoffmann et al. 2008; Schneider et al. 2009). Urban parks and their recreational usage reduce stress, aggression or fears and positively influence concentration and performance (Hartig et al. 2003). Food production in urban gardening raises awareness for local and regional products and for a healthy diet increases by gardening experiences, e.g. in community or school gardens (Lobstein et al. 2015). All the ecosystem services of NBS, as they were described above, are normally neither been assessed nor accounted for in urban decision-making although their value is increasingly recognized (regarding increases in housing prices through proximity to urban green spaces; see Kolbe and Wüstemann 2014). An informed political and administrative decision about which projects to prioritize and implement requires proper evaluation and a sound informational basis. Such basis may consist in both (i) monitoring of NBS, their functioning and the (ecosystem) services they provide, and (ii) the inclusion of natural capital stocks and flows in municipal budgets and bookkeeping systems to account for the value and return of investment in green infrastructure. For both informational systems and respective integrated management decisions, it is crucial to assess the multiple benefits that NBS provide.

\subsubsection{Fostering Cooperation}

Implementing NBS in urban areas requires an overarching integration into various municipal decision-making processes. The infrastructure department might need to collaborate with the tourism agency, and the climate change and environmental protection administration may be required to cooperate with the social and family 
department, in order to design coherent policies that minimize trade-offs to other sectors and boost synergies. For supporting and implementing nature-based solution, it is particularly important that urban green spaces do not only receive support by the respective municipal department that is directly responsible but also by other municipal departments that benefit from these NBS. Thus the creation of crossdepartmental planning and decision-making procedures within a single municipality's nature-based solution strategy may well enhance the overall performance and speed of implementation.

Furthermore, a single municipality often has limited resources and may not necessarily be able to supply the required budget, manpower and knowledge based for a suitable implementation of NBS. It may also be the case that the benefits of NBS cross municipal borders and affect neighbouring municipalities or that economies of scale, both in terms of increased provision of ecosystem services and in terms of reduced costs of implementation, can be realized when NBS are developed jointly through inter-municipal cooperation. Furthermore, to facilitate access to best-practice examples and learning from mistakes, inter-municipal exchange platforms and associations can serve as a multiplying factor in mainstreaming NBS into urban planning. While there are often existing networks, an installation of a respective working group within and between them would enhance mutual learning processes. This does not only hold for (horizontal) cooperation between municipalities but also for (vertical) cooperation between municipalities and upper governmental levels (state or federal level).

Since public administrations are by far not the only relevant land owners and land users in urban areas, a cooperation of public authorities with private initiative can facilitate an extra aid for the implementation of NBS. Urban gardening, green buildings, or even citizen science, which basically means public participation in scientific processes (cf. Bonney et al. 2009), may be ideas for enhancing monitoring and implementation of green infrastructures and their socio-economic and ecological benefits.

\subsubsection{Planning Procedures}

Urban development plans and zoning approaches are essential tools for urban decision-making and thus the integration of NBS into the respective procedures. Even in traditional administrative plans, conservation and environmental protection may be integrated already properly. In many instances, however, environmental planning is just one sectorial planning in the course of a development project and sometimes conflicting with other planning goals (such as city compaction, reducing traffic jam or the preservation of historic buildings). The idea of NBS goes further than just conservation and protection and aims at integrating different sectorial planning. The idea of NBS entails approaches where natural ecosystems may provide services that man-made alternatives cannot supply as cheaply or effectively. Since an engineer in the waste-water department may not be aware of nature-based alternatives, integrated 
planning procedures are required, where feasible and economically viable NBS are streamlined into the various urban planning procedures. However, until now the concept of ecosystem services is not or only implicitly taken into account in planning processes (Hansen et al. 2015). Due to the potential trade-offs and land-use conflicts, elaborated decision support tools such as multi-criteria analysis or environmentally extended cost-benefit analysis can supply the needed information in order to balance and counteract deadweight losses.

\subsubsection{Economic Instruments}

As has been mentioned, there is a variety of stakeholders that have different interests and ideas for the space available in urban areas. They all will opt for those alternative that offers them the best value for money, given the prevalent rules and conditions of the system in which they operate. Against this background, setting incentives by economic instruments may change these conditions, ultimately stimulating actors to pursue those other project alternative that now seems best to them. For example, a separate charge on rainwater poured into sewage systems can offer incentives to avoid soil sealing (Rüger et al. 2015). The same is true for a wastewater fee that is oriented to the sealed natural ground (Geyler et al. 2014).

Basically, there are three market-based instruments which may help accomplishing NBS, two that address private actors through either prices or quantity mechanisms and one addressing public actors such as municipalities which help in accomplishing NBS.

Price Instruments. A first type of market-based instrument is prices. A possible application of such price-based instruments is either through an incentive-oriented design of existing charges (e.g. municipal fees for water services) or levying new ones (e.g. water charges). In theory, charges shall change the price of using an ecosystem service to reflect the full cost of its provision. Fees for water services usually are based on the principle of cost recovery, often including only technical costs (investment costs, operation and maintenance costs) incurred for the provision of water to users (Gawel 1995). However, there exist margins herein, as the determination of underlying costs allows - at least in principle - to also include environmental and resource costs (Gawel 2016; Rüger et al. 2015).

Quantity Instruments. On the contrary to price-based approaches, quantitative instruments are directly limiting activities impacting natural areas, e.g. by setting a cap on the maximum amount of green fields to be developed (McConnell and Walls 2009). Within the scope of the cap development rights will be auctioned or allocated for free among potential developers. By making development rights tradable, a costefficient allocation of development can be assured as those landowners able to realize the highest net benefits from development will buy up rights and develop their land (Mills 1980). However, if such a system is to allow for a targeted protection of specific green infrastructures, it has to be accomplished by land-use zoning (Schröter-Schlaack 2013; Santos et al. 2015). 
Fiscal Instruments. While taxes set incentives for private land users, the criteria according to which the levied tax income is distributed among jurisdictions create incentives for decision-making of public authorities. Typically, fiscal transfer is assigned on the basis of comparing population numbers (as a proxy for jurisdiction's fiscal needs) and own tax revenues (as a proxy for jurisdiction's fiscal capacity), thereby stimulating communities to increase the number of inhabitants, e.g. by dedicating land for development to keep property prices low. If a portion of tax revenue would be distributed according to ecological criteria, this may set incentives for providing green infrastructures and NBS. An example may be the ecological fiscal transfers implemented in Brazil or Portugal, where municipalities receive tax revenue for hosting protected areas (Ring 2008; Santos et al. 2012).

\subsection{Obstacles and Limits for Financing Nature-Based Solutions on the Local Level}

Although there might be a broad variety of obstacles for the successful implementation of NBS in urban areas such as political resistance, path dependencies or dominant interests, we focus on the problem from the perspective of public finance and fiscal federalism (Oates 1972; Boadway and Shah 2009). Therefore, this subsection elaborates on the (missing) recognition of NBS in both the structure of municipal revenues and the competing public functions (and expenditures) that define the municipal spending behaviour. With respect to concrete legal provisions, we refer to the case of Germany. However, similar public finance restrictions can be found in many other developed countries.

\subsubsection{Financing NBS from Own Sources: The Structure of Municipal Revenues}

If NBS are to be financed, the structure of municipal revenues is decisive. Generally speaking, there are three sources of municipal revenues: (i) fees and charges for publicly provided goods and services, (ii) the revenues from municipal taxes (or the local tax revenue of shared taxes between different government levels) and (iii) the redistribution of tax revenues via fiscal transfers (either vertically from higher governmental levels or horizontally between jurisdictions of the same level). The exact structure depends on the fiscal constitution of a given country (see as a classical example Musgrave 1959) and of the given fiscal transfer system (Zimmermann 2016, Chap. 5).

Municipal Fees and Charges. Fees and charges for public services are often a substantial source of municipal revenues (Wagner 1983) and may play a significant role in financing NBS, e.g. for municipal waste management or water supply. In order to 
generate an optimal allocation of scarce resources, rates for fees and charges, however, have to follow the benefit principle of public finance: they should make sure that those benefitting from a particular service should also bear the costs (Olson 1969; Hansjürgens 2001). Fees and charges are calculated by municipalities, depending on the underlying costs of providing the service. An example is water pricing. According to Article 9 of the EU Water Framework Directive, water prices could not only be based on water-related investment costs and O\&M (operating and maintenance) costs but also on environmental and resource costs (Gawel 2016). Fees and charges can nevertheless only partly serve as instruments for financing NBS, for two reasons: Firstly, a calculation of fees and charges beyond the cost recovery principle is legally forbidden and can be fought via court decisions (Gawel 1995; Hansjürgens 1997). Only if environmental ad resource costs would be included in the calculation in fees and charges, which is currently not the case, these instruments could serve as a financing instrument for NBS. Secondly. financing of NBS through municipal fees and charges (even if environmental and resource costs are included) is always restricted to the underlying service and its costs. Additional revenues that can be spent in policy fields beyond the water or waste management sector are not possible. This clearly limits the scope of fees and charges to finance NBS on the municipal level.

Municipal Tax Revenues. A second source of municipal income is taxes that are completely or partly under the authority of municipalities, such as the property tax in Germany (Zimmermann 2016). Furthermore, municipal tax revenue may also originate from taxes that are collected at other governmental levels and then distributed to the local level, e.g. income tax in Germany.

Three observations are of particular relevance for the possibilities (and limitations) of municipal tax income to finance NBS: (1) Freedom of municipalities to raise revenues from own sources is limited due to a lack of tax competences. Most countries are unitary states with the power to tax residing with the central government - only few nations are federally organized with an independent decentral level with own powers (amongst others, the USA, Canada, Germany, Australia or Switzerland). Moreover, even in federal states it is legally not allowed to tax one and the same tax base several times. As most tax bases are already taxed by upper level governments, there is little possibility left for local levels to introduce own taxes. (2) There are a few taxes with revenue sharing between governmental levels (e.g. in Germany, the income tax of the business tax). In the case of sharing the revenues of joint taxes between different governmental levels, a decentral tax rate setting is with very few exemptions - not permitted to avoid regional differences in households' or companies' tax rates within one country. There is a high preference for achieving similar living conditions for all citizens within the country; in Germany this is even a constitutional goal. (3) In addition, a loose regulation of taxes under the authority of local governments may lead to an undesired tax competition between the respective authorities. Whether that is beneficial or not desirable is a contested issue: Many fear a "race to the bottom" if tax competences are given to lower governmental levels. Others would welcome this as an element of jurisdictional competition 
(Tiebout 1956; Oates and Schwab 1988; Zodrow 1983; Zodrow and Mieszkowski 1986; Sinn 1990; Kenyon and Kincaid 1994; Lenk 2004; Vanberg 2013).

Fiscal Transfers. Depending on the constitutional structure, whether a given country is a federal or a unitary state, the autonomy of local authorities may vary (Boadway and Shah 2009; Zimmermann et al. 2012). However, there are always some public functions that are provided by local governments. Fiscal transfers are an important means to finance these functions on the local level. In general, such transfers between upper and lower governmental levels have two goals: (i) to ensure that the municipal government level has sufficient funds to provide its public functions and (ii) to equalize differences between regions or municipalities, that is, to create a "fairer" revenue distribution. Regarding the first goal, often vertical fiscal transfers from higher government levels to lower tiers are employed - although their share of municipal income is generally higher in nonOECD countries (Shah 2007). In relation to the second goal, there are horizontal fiscal transfers, often also called fiscal equalization schemes that redistribute tax revenue from richer regions or municipalities to poorer ones. Thereby available tax revenue, e.g. per capita, is equalized but rarely to the extent of total equality. Another possibility to realize the second goal is to implement a vertical transfer system that has equalization (and thus horizontal redistribution) effects. As has been mentioned, the criteria according to which the fiscal transfers are distributed may incentivize and thus steer behaviour among (local) governments (see for a German example Baretti et al. 2002). Figure 18.2 shows an overview of fiscal transfers systems.

The scope for financing NBS solutions in such a transfer system is generally limited. Even though the general fiscal situation of a (poor) municipality may improve through such transfers, specific public expenditures for NBS can hardly be financed on this basis. Only if NBS are seen as a specific function that increases fiscal needs that corresponds to the first goal above, an additional financing might be possible.

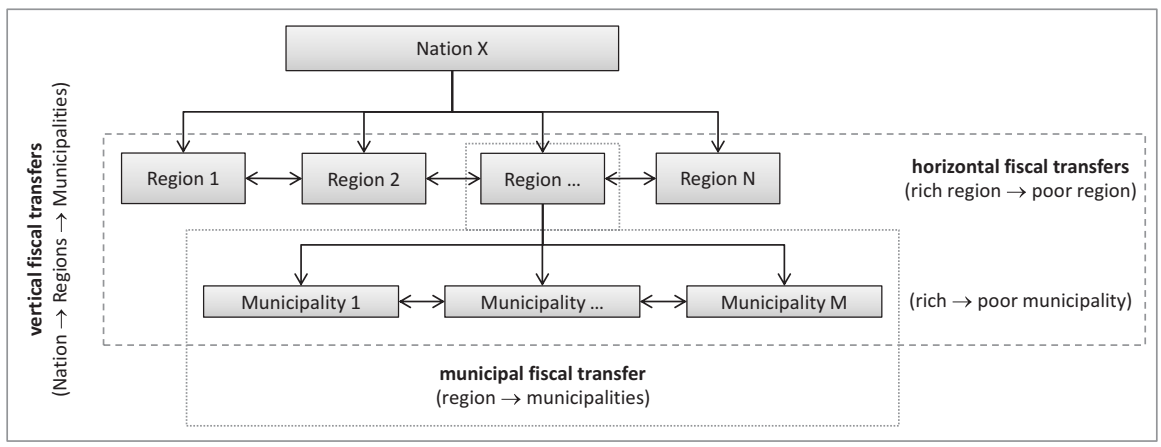

Fig. 18.2 Overview of fiscal transfers in multilevel governments (own representation) 


\subsubsection{Public Spending for NBS: Limited Municipal Autonomy for Functions and Expenditures}

Generally, there is only a limited municipal autonomy in deciding how to allocate expenditures. Most often, public functions are delegated from higher to lower levels, which require that the local governments provide public services that have been defined at higher tiers (Foldvary 1994; Zimmermann 2016).

Municipal governments have numerous functions to fulfil, and for quite a lot of these functions municipalities are (legally or de facto) urged to fulfil these functions and spend the corresponding expenditures (Zimmermann 2016). In this respect, municipal functions (and expenditures) can be classified in:

(i) Those that are fully obligatory or mandatory, because there are legal prescriptions that have to be fulfilled, without any discretionary municipal freedom. Here both the whether and how to fulfil a function are determined by upper levels.

(ii) Those that have to be taken by the local level and the task as such is prescribed by law. Here, the municipalities have discretionary power to decide how to fulfil the prescribed task (water provision or waste-water treatment may serve as an example).

(iii) Those where municipalities have "full freedom" to decide whether and how to fulfil a function (and the corresponding expenditure) (Zimmermann 2016).

In many nations the share of functions of municipalities that are legally prescribed by upper level legislation (see i) above) is often very high, while the share of "self-determined" decided functions (see iii above) tends to be quite small. Under financial pressures, these self-determined functions are the first that have to be cut down. Urban green spaces and NBS are in most cases falling into this third category of local public functions (e.g. sports and culture). In consequence, although there is discretionary power for municipalities to define whether and how NBS shall be realized, this power is quite limited in practice (at least in poorer communities where freely available money is small).

There is another limit for financing NBS: One of the constitutional principles in Germany (and similarly in other federally organized countries) is connectivity. This principle asks for a match of competencies and expenditure and basically states that who is responsible for deciding upon a public task also has to pay for its fulfilment. It points at the equivalence between public functions and public expenditures as part of the principle of fiscal equivalence (Olson 1969). The connectivity principle requires that if federal states devolve the competence to decide upon NBS to local authorities, the respective financing will also have to be borne by the latter. Given that local authorities have tight budget constraints and various public functions to fulfil, such a delegation without proper cofinancing or respective fiscal transfers will not necessarily help a better implementation of NBS. The point here is that in practice the connectivity principle is often violated: functions are delegated from upper levels to municipalities without fully compensating the 
corresponding expenditures (Zimmermann 2016). This amplifies the financial problems of local level governments, especially if they belong to the poorer ones.

Summing up the revenue and expenditure considerations of municipal public finance, the central problems for the implementation of NBS are the following: Municipal authorities play a central role in the actual planning and management of (green) infrastructure, environmental protection and nature conservation. Nevertheless, with respect to financing expenditures for investments in NBS, there is not much autonomy left to local authorities: Firstly, the fees and charges for public services such as waste and water management have to cover the costs of the service but may not exceed them. Therefore, they are not suited to generate surplus to cross finance other public functions. Secondly, the powers to raise tax revenues from own sources are rather limited. Thirdly, the income that municipalities levy through their revenues has to be spent on the variety of public functions they are responsible for. And fourthly, current systems of fiscal transfers do not recognize ecological public functions (Ring 2002). Therefore, financing NBS faces hard competition with other public functions, cannot be cross-financed from municipal fees and suffers disadvantages in the fiscal transfers system.

\subsection{Finding the Appropriate Nature-Based Solutions Policy and Funding Mix}

There are three points worth stressing to elaborate on potential approaches for leveraging investments in urban NBS.

First, NBS are multifunctional and require cross-sectoral, cross-departmental planning procedures where different vested interests may be balanced. While originating from the functionality that NBS provide, it means that also different funds have to be acquired and directed towards respective investments. A hypothetical example could be creating an attractive green space with recreational amenity services. Public health studies have shown that these urban green spaces also contribute to positive health impacts (for an overview, see Naturkapital Deutschland 2016, pp. 98). Another example may be the protection against flood risks by urban wetlands (ibid, pp. 86). These NBS could be financed not just by the environmental but also by the health or the municipal water department. Since these are rather intermunicipal decision-making procedures where different interests and power structures create path dependencies, it might be difficult to change current investment patterns through directives for interdepartment cooperation. Information of cobenefits of NBS may nevertheless be a decisive element to create more favourable conditions for corresponding investments by several municipal departments. This is to say, the clearer the "return of investment" for each of the affected sectors, the more likely are respective decision-makers to invest in such "novel" and innovative alternatives to well-known city plans. The required information may either be supplied by science or be included in administrative assessment methodologies, such as cost-benefit analyses that are extended to cover the environmental dimension 
(Hanley and Barbier 2009; Hansjürgens 2004) or multi-criteria analyses (Janssen 2001; Tsianou et al. 2013).

Second, public-private partnership may enable urban decision-makers to create alliances that create a favourable climate for investments in NBS (Naturkapital Deutschland - TEEB DE 2016). Citizens, local businesses and potentially even larger enterprises may have an interest in parks, protected areas, urban forests, clean watersheds and a livable city. Especially large enterprises with several locations prefer those with a good living condition, because that helps them to attract high-quality personnel. This opens new opportunities to engage and even support such developments financially. The more stakeholder organize in networks and associations to defend and propagate their interest in, e.g. the conservation of farmlands and forests (Bryant 2006), the more likely a success to balance these land-use pursuits with other land-use interests such as housing development. Arrangements such as Payments for Ecosystem Services (PES) may protect important areas for public services. Several cities have launched such programmes to support their public service provider such as the municipal water utilities to maintain and conserve peri-urban and rural watersheds that supply clean drinking water naturally. It is worth noting that there are, however, critics of such approaches - since they seem to commoditize nature (see, e.g. Fletcher 2014). Nevertheless, there might however be private public partnership approaches that serve the goal of providing NBS without the turmoil of a supposedly sellout of nature (Kallis et al. 2013; Hansjürgens 2015).

Third, the proper integration of ecological public functions within the fiscal constitution may well help and enhance the implementation of NBS in urban areas (Naturkapital Deutschland - TEEB DE 2016). Creating incentives not just for private land users through price mechanisms like taxes and cap-and-trade-based mechanisms for development rights, but essentially incentivizing nature-affine investment behaviour of public authorities, may constitute a well-functioning but not yet well-known addition in the policy mix. It has been shown that the integration of ecological indicators in municipal fiscal transfers incentivizes the respective governments to create additional protected areas (Sauquet et al. 2014; Droste et al. 2015; Ring 2008). Depending on the indicator, also urban green spaces and their ecological public functions could be supported through ecological fiscal transfer mechanisms. Basically, the incentive would function the following way: If a city would receive a portion of fiscal transfers only if it supplied a certain amount of green spaces per capita - to construct an easy example - it might be profitable for the city to invest a certain amount to assure such additional income. By integrating an ecological indicator into the fiscal transfer system, a financial aspect comes into play that may incentivize investments into NBS - whether it actually does might ultimately rather be a question of the amount that can be gained through such investments and the local (opportunity) costs.

Through highlighting three potential routes of how investments into NBS may be supported (inner-municipal cooperation, public-private partnerships and ecological fiscal transfers), it becomes clear that there are different leverage points and that a coherent policy has to be thought in form of a policy mix (cf. Ring and Barton 2015). It also becomes clear that there are different funds available from which such investments may be financed: municipal budgets, public-private funds or fiscal 
transfer funds. Thus, there is no one-size-fits-all panacea but a toolbox of potentially suitable instruments which may be employed with greater or lesser success in different circumstances.

\subsection{Concluding Remarks}

We have started by introducing potential instruments for implementing NBS and discussed how difficult it may be to leverage finance to implement them. We ended by presenting three ideas how the required investments may be levied: (i) reorganizing decision-making structure within municipalities to free funds to finance (economic) side benefits of NBS, (ii) organizing alliances and private-public partnership with a vested interest in a clean and green city and (iii) integrating ecological indicators in municipal fiscal transfer systems. These instruments are more likely successful when embedded in a nature-based solution policy mix.

\section{References}

Baretti C, Huber B, Lichtblau K (2002) A tax on tax revenue: the incentive effects of equalizing transfers: evidence from Germany. Int Tax Public Financ 9(6):631-649

Boadway R, Shah A (2009) Fiscal federalism: principles and practices of multiorder governance. Cambridge University Press, Cambridge

Breton A (1996) Competitive governments. An economic theory of politics and public finance. Cambridge University Press, Cambridge

Bryant MM (2006) Urban landscape conservation and the role of ecological greenways at local and metropolitan scales. Landsc Urban Plan 76(1-4):23-44

Bonney R, Cooper CB, Dickinson J, Kelling S, Phillips T, Rosenberg KV, Shirk J (2009) Citizen science: a developing tool for expanding science knowledge and scientific literacy. Bioscience 59(11):977-984

Droste N et al (2015) Ecological Fiscal Transfers in Brazil - incentivizing or compensating conservation? In: Paper presented at the 11th international conference of the European Society for Ecological Economics (ESEE). Leeds

EC (2015) Towards an EU Research and Innovation policy agenda for Nature-Based Solutions \& Re-Naturing Cities, European Commission. Available at: http://bookshop.europa.eu/en/towardsan-eu-research-and-innovation-policy-agenda-for-nature-based-solutions-re-naturing-citiespbKI0215162/

Fletcher R (2014) Orchestrating consent: post-politics and Intensification of Nature (TM) Inc. at the 2012 World Conservation Congress. Conserv Soc 12(3):329-342

Foldvary F (1994) Public goods and private communities. Edward Elgar, Cheltenham

Gabriel K, Endlicher W (2011) Urban and rural mortality rates during heat waves in Berlin and Brandenburg, Germany. Environ Pollut 159(8):2044-2050

Gawel E (1995) Die kommunalen Gebühren. Duncker \& Humblot, Berlin

Gawel E (2016) Environmental and resource costs under Article 9 water framework directive. Challenges for the implementation of the Principle of Cost Recovery For Water Services. Duncker \& Humblot, Berlin

Geyler S, Bedtke N, Gawel E (2014) Nachhaltige Regenwasserbewirtschaftung im Siedlungsbestand - Teil 2: Kommunale Strategien und aktuelle Steuerungstendenzen. gwf Wasser I Abwasser 2:214-222 
Hanley N, Barbier EB (2009) Pricing nature: cost-benefit analysis and environmental policy. Edward Elgar, Cheltenham

Hansen R et al (2015) The uptake of the ecosystem services concept in planning discourses of European and American cities. Ecosyst Serv 12:228-246

Hansjürgens B (1997) Gebührenkalkulation auf Basis volkswirtschaftlicher Kosten. Anwendungsprobleme und Lösungsmöglichkeiten. Archiv für Kommunalwissenschaften 36:233-253

Hansjürgens B (2001) Äquivalenzprinzip und Staatsfinanzierung. Duncker \& Humblot, Berlin

Hansjürgens B (2004) Economic valuation through cost-benefit analysis - possibilities and limitations. Toxicology 205(3):241-252

Hansjürgens B (2015) Wider Irrläufer und Fehlinterpretationen. Ökologisches Wirtschaften $30(2): 8-9$

Hartig T et al (2003) Tracking restoration in natural and urban field settings. J Environ Psychol 23:109-123

Heudorf U, Meyer C (2005) Gesundheitliche Auswirkungen extremer Hitze am Beispiel der Hitzewelle und der Mortalität in Frankfurt am Main im August 2003. Gesundheitswesen 67:369-374

Hoffmann B et al (2008) Increased cause-specific mortality associated with 2003 heat wave in Essen, Germany. J Toxicol Environ Health 71(11/12):759-765

IUCN (2016) Nature-based solutions. Available at: http://www.iucn.org/regions/europe/our-work/ nature-based-solutions. Accessed 30 June 2016

Janssen R (2001) On the use of multi-criteria analysis in environmental impact assessment in The Netherlands. J Multi-Criteria Decis Anal 10:101-109

Kallis G, Gómez-Baggethun E, Zografos C (2013) To value or not to value? That is not the question. Ecol Econ 94:97-105

Kenyon DA, Kincaid J (eds) (1994) Competition among states and local governments - efficiency and equity in American Federalism. The Urban Institute Press, Washington, DC

Kolbe J, Wüstemann H (2014) Estimating the value of urban green spaces: a hedonic pricing analysis of the housing market in Cologne, Germany. Folia Oeconomica 5(307):45-61

Lenk T (2004) Mehr Wettbewerb im bundesstaatlichen Finanzausgleich? Eine allokative und distributive Wirkungsanalyse für das Jahr 2005 unter Berücksichtigung der Neuregelungen. Jahrbücher für Nationalökonomie und Statistik 224(3):351-378

Lobstein $\mathrm{T}$ et al (2015) Child and adolescent obesity: part of a bigger picture. Lancet 385(9986):2510-2520

McConnell V, Walls M (2009) U.S. experience with transferable development rights. Rev Environ Econ Policy 3:288-303

Mills D (1980) Transferable development rights markets. J Urban Econ 7:63-74

Musgrave RM (1959) The theory of public finance: a study in public economy. McGraw-Hill, New York

Naturkapital Deutschland - TEEB DE (2016) Ökosystemleistungen in der Stadt - Gesundheit schützen und Lebensqualität erhöhen. Technische Universität Berlin, Helmholtz-Zentrum für Umweltforschung - UFZ, Berlin/Leipzig

Oates WE (1972) Fiscal federalism. Harcourt Brace Jovanovich, New York

Oates WE, Schwab RM (1988) Economic competition among jurisdictions: efficiency enhancing or distortion inducing? J Public Econ 35(3):333-354

Olson M (1969) The principle of "fiscal equivalence": the division of responsibilities among different levels of government. Am Econ Rev 59(2):479-487

Potschin M, et al (2015). Nature-based solutions. In: Potschin M, Jax K (eds) OpenNESS Ecosystem Service Reference Book. OpenNESS Synthesis Paper. Available at: http://www. openness-project.eu/library/reference-book/sp-NBS

Ring I (2002) Ecological public functions and fiscal equalisation at the local level in Germany. Ecol Econ 42:415-427

Ring I (2008) Integrating local ecological services into intergovernmental fiscal transfers: the case of the ecological ICMS in Brazil. Land Use Policy 25(4):485-497

Ring I, Barton DN (2015) Economic instrumtents in policymixes for biodiversity conservation and ecosystem governance. In: Martínez-Alier J, Muradian R (eds) Handbook of ecological economics. Edward Edgar, Cheltenham, pp 413-449 
Rüger J, Gawel E, Kern K (2015) Reforming the German rain water charge - approaches for an incentive-oriented but still workable design of the charge. GWF - Wasser, Abwasser 156(3):364-372

Santos R et al (2012) Fiscal transfers for biodiversity conservation: the Portuguese local finances law. Land Use Policy 29(2):261-273

Santos R, Schröter-Schlaack C, Antunes P, Ring I, Clemente P (2015) Reviewing the role of habitat banking and tradable development rights in the conservation policy mix. Environ Conserv 42:294-305

Sauquet A, Marchand S, Féres J (2014) Protected areas, local governments, and strategic interactions: the case of the ICMS-Ecológico in the Brazilian state of Paraná. Ecol Econ 107:249-258

Schneider A et al (2009) Ursachenspezifische Mortalität, Herzinfarkt und das Auftreten von Beschwerden bei Herzinfarktüberlebenden in Abhängigkeit von der Lufttemperatur in Bayern (MOHIT). Helmholtz-Zentrum München - Deutsches Forschungszentrum für Gesundheit und Umwelt, Institut für Epidemiologie, München

Schröter-Schlaack C (2013) Steuerung der Flächeninanspruchnahme durch Planung und handelbare Flächenausweisungsrechte. Helmholtz-Zentrum für Umweltforschung - UFZ, Leipzig

Shah A (2007) A practitioner's guide to intergovernmental fiscal transfers. In: Boadway R, Shah A (eds) Intergovernmental fiscal transfers: principles and practices. World Bank, Washington, DC, pp 1-54

Sinn HW (1990) Tax harmonization and tax competition in Europe. Eur Econ Rev 34(2-3):489-504

TEEB (2012) In: Wittmer H, Gundimeda H (eds) The economics of ecosystems and biodiversity for local and regional policy makers. Earthscan, London/Washington

ten Brink P et al (2012) Nature and its role in the transition to a green economy. Institute for European Environmental Policy, Brussels

Tiebout CM (1956) A pure theory of public expenditures. J Polit Econ 64:416-424

Tsianou MA et al (2013) Identifying the criteria underlying the political decision for the prioritization of the Greek Natura 2000 conservation network. Biol Conserv 166:103-110

Vanberg VJ (2013) Föderaler Wettbewerb, Bürgersouveränität und die zwei Rollen des Staates, Freiburg Discussion Papers on Constitutional Economics 13(3). Walter Eucken Institut

Wagner RE (1983) Public finance, revenues and expenditures in a democratic society. Little Brown, Boston

World Bank (2008) Biodiversity, climate change and adaptation - nature-based solutions from the World Bank Portfolio. World Bank, Washington, DC

Zimmermann H (2016) Kommunalfinanzen: Eine Einführung in die finanzwissenschaftliche Analyse der kommunalen Finanzwissenschaft, 3rd edn. Berliner Wissenschaftsverlag, Berlin

Zimmermann H, Henke K-D, Broer M (2012) Finanzwissenschaft: eine Einführung in die Lehre von der öffentlichen Finanzwirtschaft, 11th edn. Vahlen, München

Zodrow GR (ed) (1983) Local provision of public services. The tiebout-model after twenty-five years. Academic Press, New York

Zodrow GR, Mieszkowski P (1986) Pigou, Tiebout, property taxation, and the underprovision of local public goods. J Urban Econ 19(3):356-370

Open Access This chapter is licensed under the terms of the Creative Commons Attribution 4.0 International License (http://creativecommons.org/licenses/by/4.0/), which permits use, sharing, adaptation, distribution and reproduction in any medium or format, as long as you give appropriate credit to the original author(s) and the source, provide a link to the Creative Commons license and indicate if changes were made.

The images or other third party material in this chapter are included in the chapter's Creative Commons license, unless indicated otherwise in a credit line to the material. If material is not included in the chapter's Creative Commons license and your intended use is not permitted by statutory regulation or exceeds the permitted use, you will need to obtain permission directly from the copyright holder. 